\title{
The Survey of Graduated Accounting Students’ Interest in Management Accounting: Evidence of Iran
}

\author{
Rezvan Hejazi, Ameneh Bazrafshan* \\ Faculty of Social and Economic, Alzahra University, Tehran, Iran \\ Email: *bazrafshan_63@yahoo.com
}

Received December 27, 2012; revised February 1, 2013; accepted March 9, 2013

Copyright (C) 2013 Rezvan Hejazi, Ameneh Bazrafshan. This is an open access article distributed under the Creative Commons Attribution License, which permits unrestricted use, distribution, and reproduction in any medium, provided the original work is properly cited.

\begin{abstract}
The purpose of this study is to investigate the perceptions of graduated accounting students in universities of Iran regarding their interest in management accounting versus other fields of accounting. Furthermore, this study determines the main factors that influence students' interest in management accounting. In order to compile the necessary information, a questionnaire was prepared and distributed to 75 graduated accounting students. The results show that accounting students prefer financial accounting and auditing rather than management accounting. Moreover, findings indicate nine factors decline students' interest in this branch of the accounting. Finally, using factor analysis, the results confirm the significant effect of three factors on students' interest: education, profession, research. The paper provides additional empirical evidence to clarify which factors cause a low interest in management accounting.
\end{abstract}

Keywords: Management Accounting; Interest; Universities of Iran

\section{Introduction}

Increasing the complexity of the business environment, important changes in the nature of business, and increasing the competition with high powered computing technology, have contributed to the development of new management accounting techniques and consequently, have resulted in a considerable amount of attention to management accounting in the world. Therefore, firms have to consider new management accounting techniques and revise traditional cost accounting and management control systems.

Applied management accounting in countries, articularly in Iran, is influenced by numerous economical, social and cultural factors. After the win of the Islamic revolution and the foundation of the Islamic Republic of Iran, and following that, the beginning of the imposed war with Iraq, the government controlling many industries and economic activities seemed inevitable.

After the end of the war, the government initiated programs for socioeconomic reconstruction and reform in the framework of the first and second development plans aiming to increase productivity of government firms and a more dynamic presence of the private sector in the national economy. Particularly, in 2007, Supreme Leader

\footnotetext{
"Corresponding author.
}

Ayatollah Khamenei requested that government officials speed up the implementation of the policies outlined in the improvement of Article $44^{1}$, and move toward economic privatization. Ayatollah Khamenei also suggested that ownership rights should be protected in courts set up by the Justice Ministry; the hope was that this new protection would give an additional measure of security and support private investment.

Proceeding with this course, in accordance with the law of the third development plan, the program to privatize government firms continued by organizing government firms in order to convey their stocks to the private sector. Moreover, throughout the fourth development plan, the principle of privatization continued based on the same process [1]. Hence, the firms move to the point to

\footnotetext{
${ }^{1}$ According to Principle 44 of the Constitution, the economic system of the Islamic Republic of Iran is based on the three pillars of government cooperative, and private sector and is maintained by correct and ordered planning. The government sector includes all large industries, parent industries, international commerce, large mines, banking, insurance, energy, dams and large waterway networks, radio and television, post, telegraph and telephone, shipping lines, roads, railroads and similar things. The cooperative sector includes institutions and companies involved in manufacturing and distribution that are established in cities and villages in accordance with Islamic criteria. The private sector includes those parts of agriculture, livestock, industries, and services that are supplementary to the economic activities of the government and cooperatives (Ministry of finance, 2008).
} 
properly manage resources, minimize cost and maximize profitability. So they consider designing and implementing new and appropriate management accounting techniques.

In Iran, on one hand, cultural characteristics such as deterministic view, uncertainty avoidance and power distance, do not lead to developing management accounting and, on the other hand, collectivism and the importance of social value and egalitarian lead to more developing management accounting and increasing the implementation of new management accounting techniques in firms [2]. For example, the factor of the deterministic view makes practitioners place an emphasis on traditional management accounting techniques [3].

The need for accounting graduates is growing. Therefore, the identification of their perceptions is very important. Since management accounting is one of the main fields of accounting and plays a very important role within firms in all industry sectors (e.g. Manufacturing and services), in Iran, there is, generally, less emphasis on and interest in the management accounting profession in comparison to the financial accounting profession among accounting students. In other words, there is low concern about management accounting among accounting students ${ }^{2}$.

Discovering the factors affect in accounting students' interest in management accounting can be useful in training students for future roles in management accounting and involve teaching techniques that will be useful to their organizations to the present and the future [4].

The purpose of this study is to investigate the accounting student perceptions of management accounting and identify the important factors affecting their interest. The current findings indicate that there is a lack of interest in management accounting among students in comparison to financial accounting. Moreover, the findings indicate that factors of education, research, and profession influence students' interest in this branch of the accounting profession.

The remainder of this paper is organized as follows. The next section reviews literature and developed the study's hypotheses. This is followed by details of the methodology, sample and the survey conducted on students. Then, research results are presented. The last sec-

\footnotetext{
${ }^{2}$ Several universities in Iran, from the early 1950s, have been offering programs of studies in accounting. The accounting program of each university was based on a curriculum heavily influenced by AngloAmerican accounting programs. After the evolution, all universities in Iran have been conducting their accounting programs on the basis of this single curriculum designed by the government. Now there are more than 2400 Universities, 500,000 Undergraduate students, 25,000 graduated students and $1000 \mathrm{Ph} . \mathrm{D}$. in Accounting in Iran. Also, in some universities, there are diverse field of accounting like managerial accounting, Auditing, tax accounting, governmental accounting and so on.
}

tion presents conclusion and recommendations.

\section{Literature Review and Hypotheses Development}

There are not broad researches about accounting students' interest in management accounting. But generally, former researches have acknowledged that management accounting has lower perceived value than financial accounting. For example, management accounting professional certificates were not popular when compared with the other ones.

One of the factors that might influence students' interest is educational context focusing on financial rather than managerial accounting and management accounting, is considered to be dominated by financial accounting [5]. Also, the existence of a possible "gap" in management accounting between theory and practice is important.

Surveying undergraduate accounting students at a university in the USA, some researchers [6] found that $76 \%$ students were interested in pursuing the Certified Public Accountant (CPA) rather than CMA. They showed that students prefer public accounting as their first choice of career while private industry accounting and working for the federal government offer desirable jobs as well. In addition, other researchers $[7,8]$ found that most of the students were interested in pursuing and preferring (CPA) rather than CMA. However, there is some evidence in some countries such as the UK that provides a highly interest's management accounting professional qualification [9]. Furthermore, it has observed [10] that accounting students prefer public accounting as their first choice of career rather than management accounting. Job opportunities and income were the most significant factors that discouraged students from being interested in the management accounting profession. Moreover, it is recommended that support from companies to pursue the management accounting profession was the most important suggested factor to enhance students' interest in this branch of the accounting profession. Students prefer the jobs in public accounting in industrial accounting. Moreover, the students from four US universities would consider public accounting more professionally and socially satisfying than industrial accounting [11].

In investigating the impact of culture, budgetary participation, and management accounting systems on managerial performance in Iran, it is observed that the application of management tools and techniques developed in western countries for effective management performance is not useful in the Iranian context [12].

Previous studies, conceptually or empirically has mentioned some factors that influence students' interest in management accounting. For example, some researchers [13] believe salary; opportunities for advancement, working setting, job security, and educational program affect 
accounting students' job selection decisions. Some other researches indicate doing something valuable, good work rewarded, job intellectually stimulating, and prepare self for the advancement and use of specific education/abilities are also important [14]. It is said that some factors that might impact students' interest are as follows: intellect, personal styles, job prospects, family background, parental pressures, perceptions of different disciplines, culture, first accounting principles course, accounting instructors parents, relatives, or friends, market focus, and the curricular options made available by universities [10]. Also, firm personnel, opportunities for advancement and firm location are important factors in interest in management accounting [15].

Nevertheless, the most recent studies did not present a theoretical reason for studying the influence of such factors, which makes it difficult to generalize such results [16]. Given to former points, we develop our hypothesis as follows:

H1: There is less interest in management accounting when compared to the financial accounting.

H2: The shortage of job opportunities decreases students' interest in management accounting.

H3: low income decreases students' interest in management accounting.

H4: The absence of interest of family and friends in management accounting decreases students' interest in it.

H5: The difficulty of management accounting learning decreases students' interest in it.

H6: The shortage of appropriate text books about management accounting decreases students' interest in it.

H7: The unawareness of management accounting certificates decreases students' interest in management accounting.

H8: The shortage of seminars and workshops about management accounting decreases students' interest in it.

H9: The widespread knowledge required for management accounting decreases students' interest in it.

H10: The existed limitations and barriers to research in the context of management accounting decreases students' interest in it.

H11: The firms' disinterest in implementing management accounting new techniques decreases students' interest in management accounting.

H12: The university's engagement in merely theoretical matters decreases students' interest in management accounting.

H13: The absence of sufficient courses about management accounting in universities decreases students' interest in it.

H14: Journals' ignorance of management accounting decreases students' interest in it.

H15: The absence of sufficient curriculums in universities about management accounting decreases stu- dents' interest in it.

\section{Methodology}

This research uses the survey research method. This study has two main objectives: first, the study investigates accounting students' interest in Iran universities in comparison to other accounting areas. So, the sign test is used to meet this objective. Second, the study also seeks to determine what factors influence the decreasing of student's interest. So, the binomial test is used to fulfil this objective. To determine the reliability of the questionnaire, coefficient alpha Cronbach is used.

In order to compile the necessary information, a questionnaire was prepared and distributed to 75 graduated accounting students. The questionnaire was divided into three data-capturing sections. The first part of the survey includes questions involving demographic profile of the respondents. In the second part of the survey, students were asked to provide relative rankings of 5 branches of accounting. In the third part of the survey, a five-point Likert scale was used to determine the relative agreement of possible factors that might influence the decreasing of the student's interest in management accounting. A rating of five suggested that ranging from strongly disagree to strongly agree.

The appropriateness of this questionnaire was tested through a reliability analysis. Cronchbach's alpha test was used to check the reliability of the scale. The alpha coefficient for the entire set of questions was 0.802 , suggesting that the items had sufficient internal consistency.

\section{Results}

Table 1 reports demographic information about the respondents. 75 students participated in the survey consisting of 49 males $(61.33 \%)$ and 36 females $(38.66 \%)$ students. The mean scores of 38 students $(50.66 \%)$ were over 17 and 37 students (49.33\%) were under 17 . Only 16 students $(21.33 \%)$ reported that they did not have any professional experience and 19 students $(25.33 \%)$ had professional experience less than 2 years and 40 students $(53.33 \%)$ reported that they had professional experience more than 2 years.

Respondents were asked to state their interest in management accounting and arrange them in terms 1 to 5 in the way that the number 5 is indicative of the highest interest and 1 is indicative of the least interest. Table 2 shows the means of grade in total sample and subsamples of male and female. Financial accounting has attracted the most interests among students. Auditing took the second place, and management accounting got the third. There were similar results for a subsample of male and female.

In order to compare students' arrangement of financial 
Table 1. Descriptive statistics of the sample.

\begin{tabular}{ccc}
\hline & Frequency & Percentage \\
\hline Gender: & 29 & $38.66 \%$ \\
Female & 46 & $61.33 \%$ \\
Male & & $50.66 \%$ \\
Mean of scores: & 38 & $49.33 \%$ \\
Upper from 17 & 37 & $21.33 \%$ \\
Lower from 17 & & $25.33 \%$ \\
Professional experience: & 16 & 19 \\
No professional experience & 40 & $53.33 \%$ \\
Professional experience lower from 2 years & & \\
Professional experience upper from 2 years & & \\
\hline
\end{tabular}

Table 2. Students' rankings of level interest in accounting fields.

\begin{tabular}{cccc}
\hline Mean of grades & Total sample & Subsample of male & Subsample of female \\
\hline Financial accounting & 4.05 & 4.21 & 3.79 \\
Management accounting & 3.17 & 3.19 & 3.13 \\
Auditing & 3.36 & 3.45 & 3.21 \\
Taxation accounting & 2.29 & 2.35 & 2.21 \\
Governmental accounting & 2 & 1.85 & 2.76 \\
Sifference between financial accounting and management accounting & $\mathrm{Z}=-3.233$ & Sig $=0.001$ \\
\hline
\end{tabular}

accounting and management accounting, we use sign test. Since the coefficients obtained from sign test analysis achieved a significant level $(\mathrm{p}<0.05)$, there is a significant difference between interest in financial accounting and management accounting.

In order to test hypotheses 2 to 15 , the binomial test is used while the proportion is considered 0.6 because the proportion of 3 to 5 is $0.6(3 / 5)$. The lower than 0.6 the proportion of agreement is, the more agreement with above factors exists.

H0: $\mathrm{P} \geq 0.6$

(agreement is not high)

H1: $\mathrm{P}<0.6$

(agreement is high)

The investigation results of the students' perceptions of the most important decreasing factor of their interest in management accounting are presented in Table 3. Since the significance of variables of the job opportunities' shortage and required widespread knowledge of management accounting are greater than 0.05 , the hypothesis of equality of the proportion agreement in 0.6 is accepted. However, regarding other variables, hypothesis of equality of the proportion to 0.6 is rejected. Thus, the perceived proportion of the first group is compared to 0.6 . When it is lower than 0.6 , the agreement is high and vice versa. As a result, students agree that the shortage of appropriate text books about management accounting, unawareness of management accounting certificates, the shortage of seminars and workshops about management accounting, the existence of limitations and barriers to research in the field of management accounting, firms' disinterest in implementing new management accounting techniques, engaging universities in merely theoretical matters, the absence of sufficient courses about management accounting in universities, the journals' ignorance of management accounting, the absence of sufficient curriculum in universities about management accounting decrease their interest in management accounting.

They also believe that low income, the absence of interest of family and friends in management accounting and the hardness of its learning might not influence their interest in management accounting. Given to Table 2, men are some more interested in management accounting than women (3.19 versus 3.13$)^{3}$.

Exploratory factor analysis is a method of analysis that allows us to condense the information in the survey to a smaller set of factors with a minimum loss of information and discover the underlying structure of a relatively large set of variables. The Kaiser-Meyer-Olkin statistic was 0.78 , well above the cut-off point of 0.6 , and Bartlett's test of sphericity was significant (Sig: 0.000), both indicating that factor analysis was appropriate. We used varimax rotation, which is the most widely used orthogonal rotation method, to facilitate the interpretation of factors. Factor analysis yielded three factors with eigenvalues above 1.0. The results of factor analysis are

\footnotetext{
${ }^{3}$ Because high mean of scores students and low mean of scores students are not different from interested in management accounting point of view, we don't show their statistics.
} 
Table 3. Results of binomial test.

\begin{tabular}{|c|c|c|c|c|c|c|}
\hline & & Category & $\mathrm{N}$ & Observed Prop. & Test Prop. & Sig (1-tailed) \\
\hline \multirow{4}{*}{ The shortage of job opportunities } & Group 1 & $<=3$ & 40 & 0.5 & 0.6 & $0.145^{\mathrm{a}, \mathrm{b}}$ \\
\hline & Group 2 & $>3$ & 35 & 0.5 & & \\
\hline & Total & & 75 & 1.0 & & \\
\hline & Group 1 & $<=3$ & 54 & 0.7 & 0.6 & $0.021^{\mathrm{b}}$ \\
\hline \multirow[t]{3}{*}{ Low income } & Group 2 & $>3$ & 21 & 0.3 & & \\
\hline & Total & & 75 & 1.0 & & \\
\hline & Group 1 & $<=3$ & 54 & 0.7 & 0.6 & $0.021^{\mathrm{b}}$ \\
\hline \multirow[t]{3}{*}{$\begin{array}{l}\text { The absence of interest of family and friends in man- } \\
\text { agement accounting }\end{array}$} & Group 2 & $>3$ & 21 & 0.3 & & \\
\hline & Total & & 75 & 1.0 & & \\
\hline & Group 1 & $<=3$ & 55 & 0.7 & 0.6 & $0.011^{\mathrm{b}}$ \\
\hline \multirow[t]{3}{*}{ The hardness of management accounting learning } & Group 2 & $>3$ & 20 & 0.3 & & \\
\hline & Total & & 75 & 1.0 & & \\
\hline & Group 1 & $<=3$ & 37 & 0.5 & 0.6 & $0.040^{\mathrm{a}, \mathrm{b}}$ \\
\hline \multirow[t]{3}{*}{$\begin{array}{c}\text { The shortage of appropriate text books about man- } \\
\text { agement accounting }\end{array}$} & Group 2 & $>3$ & 38 & 0.5 & & \\
\hline & Total & & 75 & 1.0 & & \\
\hline & Group 1 & $<=3$ & 29 & 0.4 & 0.6 & $0.000^{\mathrm{a}, \mathrm{b}}$ \\
\hline \multirow[t]{3}{*}{ Unawareness of management accounting certificates } & Group 2 & $>3$ & 46 & 0.6 & & \\
\hline & Total & & 75 & 1.0 & & \\
\hline & Group 1 & $<=3$ & 20 & 0.3 & 0.6 & $0.000^{\mathrm{a}, \mathrm{b}}$ \\
\hline \multirow[t]{3}{*}{$\begin{array}{l}\text { The shortage of seminars and workshops about man- } \\
\text { agement accounting }\end{array}$} & Group 2 & $>3$ & 55 & 0.7 & & \\
\hline & Total & & 75 & 1.0 & & \\
\hline & Group 1 & $<=3$ & 40 & 0.5 & 0.6 & $0.145^{\mathrm{a}, \mathrm{b}}$ \\
\hline \multirow[t]{3}{*}{$\begin{array}{l}\text { Widespread knowledge required for management } \\
\text { accounting }\end{array}$} & Group 2 & $>3$ & 35 & 0.5 & & \\
\hline & Total & & 75 & 1.0 & & \\
\hline & Group 1 & $<=3$ & 29 & 0.4 & 0.6 & $0.000^{\mathrm{a}, \mathrm{b}}$ \\
\hline \multirow[t]{3}{*}{$\begin{array}{l}\text { Existed limitations and barriers to research in context } \\
\text { of management accounting }\end{array}$} & Group 2 & $>3$ & 46 & 0.6 & & \\
\hline & Total & & 75 & 1.0 & & \\
\hline & Group 1 & $<=3$ & 18 & 0.2 & 0.6 & $0.000^{\mathrm{a}, \mathrm{b}}$ \\
\hline \multirow[t]{3}{*}{$\begin{array}{l}\text { Firms' disinterest in implementing management ac- } \\
\text { counting new techniques }\end{array}$} & Group 2 & $>3$ & 57 & 0.8 & & \\
\hline & Total & & 75 & 1.0 & & \\
\hline & Group 1 & $<=3$ & 11 & 0.1 & 0.6 & $0.000^{\mathrm{a}, \mathrm{b}}$ \\
\hline \multirow[t]{2}{*}{ Engaging universities in merely theoretical matters } & Group 2 & $>3$ & 64 & 0.9 & & \\
\hline & Total & & 75 & 1.0 & & \\
\hline \multirow{2}{*}{$\begin{array}{l}\text { The absence of sufficient courses about management } \\
\text { accounting in universities }\end{array}$} & Group 1 & $<=3$ & 18 & .2 & 0.6 & $0.000^{\mathrm{a}, \mathrm{b}}$ \\
\hline & Group 2 & $>3$ & 57 & 0.8 & & \\
\hline
\end{tabular}




\section{Continued}

\begin{tabular}{|c|c|c|c|c|c|c|}
\hline & Total & & 75 & 1.0 & \multirow[b]{2}{*}{0.6} & \multirow[b]{2}{*}{$0.013^{\mathrm{a}, \mathrm{b}}$} \\
\hline \multirow{3}{*}{ Journals' ignorance of management accounting } & Group 1 & $<=3$ & 35 & 0.5 & & \\
\hline & Group 2 & $>3$ & 40 & 0.5 & \multirow{5}{*}{0.6} & \multirow{5}{*}{$0.000^{\mathrm{a}, \mathrm{b}}$} \\
\hline & Total & & 75 & 1.0 & & \\
\hline \multirow{3}{*}{$\begin{array}{l}\text { The absence of sufficient curriculums in universities } \\
\text { about management accounting }\end{array}$} & Group 1 & $<=3$ & 26 & 0.3 & & \\
\hline & Group 2 & $>3$ & 49 & 0.7 & & \\
\hline & Total & & 75 & 1.0 & & \\
\hline
\end{tabular}

${ }^{\mathrm{a}}$ Alternative hypothesis states that the proportion of cases in the first group $<0.6 ;{ }^{\mathrm{b}}$ Based on $\mathrm{Z}$ Approximation.

presented in Table 4.

Communalities of each item were above 0.3 , indicating that all items were explained satisfactorily by the factor solution. The three resulting dimensions from the factor analysis explain $67 \%$ of the variance in the original variables. The results in Table 3 indentify three factors of decreasing students' interest in management accounting. The first factor $\left(F_{1}\right)$ is labeled "education", $F_{2}$ "profession" and $\mathrm{F}_{3}$ "research". $\mathrm{F}_{1}$ "education": This factor includes the variables of the absence of sufficient courses about management accounting in universities, the absence of sufficient curriculum in universities, and the engagement of universities in merely theoretical and the shortage of appropriate text books about management accounting.

$\mathrm{F}_{2}$ "research": This factor includes variables of the unawareness of management accounting certificates and the shortage of seminars and workshops about management accounting. $F_{3}$ "research": This factor includes the variables of the existed limitations and barriers to re- search in the field of management accounting, the journals ignorance of management accounting and firms disinterest in implementing management accounting new techniques.

\section{Conclusions and Recommendations}

This study investigates the interest of accounting students in management accounting in universities of Iran. Furthermore, it examines the factors that may decrease students' interest in this branch of accounting. The results of this study show that students prefer financial accounting and auditing to management accounting. Moreover, the current findings indicate that students believe that the shortage of appropriate text books about management accounting, unawareness of management accounting certificates, the shortage of seminars and workshops about management accounting, the existed limitations and barriers to research in the field of management accounting, firms' disinterest in implementing management accounting new techniques, engaging universities in mere-

Table 4. Results of factor analysis.

\begin{tabular}{|c|c|c|c|}
\hline & $\mathrm{F}_{1}$ Education & $\mathrm{F}_{2}$ Profession & $\mathrm{F}_{3}$ Research \\
\hline The absence of sufficient courses about management accounting in universities & 0.842 & & \\
\hline Absence of sufficient curriculums in universities & 0.783 & & \\
\hline Engaging universities in merely theoretical matters & 0.525 & & \\
\hline The shortage of appropriate text books about management accounting & 0.518 & & \\
\hline Unawareness of management accounting certificates & \multicolumn{3}{|c|}{0.822} \\
\hline The shortage of seminars and workshops about management accounting & \multicolumn{3}{|c|}{0.752} \\
\hline Existed limitations and barriers to research in context of management accounting & & & 0.860 \\
\hline Journals' ignorance of management accounting & \multicolumn{3}{|r|}{0.401} \\
\hline Firms' disinterest in implementing management accounting new techniques & \multicolumn{3}{|r|}{0.305} \\
\hline Number of variables & 4 & 2 & 3 \\
\hline$\%$ of Cumulative Variance & 24.880 & 21.190 & 19.401 \\
\hline$\%$ of Cumulative Variance & 26.880 & 48.069 & 67.470 \\
\hline KMO Measure of Sampling Adequacy & \multicolumn{3}{|c|}{0.78} \\
\hline Bartlett's Test of Sphericity & \multicolumn{3}{|c|}{$X_{2}=222.516$, df: 36, Sig: 0,000} \\
\hline
\end{tabular}


ly theoretical matters, the absence of sufficient courses about management accounting in universities, journals' ignorance of management accounting, the absence of sufficient curriculum in universities about management accounting lead to a decrease in students' interest in management accounting. While they believe low income and the absence of interest of family and friends do not affect their interest. Finally, using factor analysis, we found three factors of education, profession and research influencing the students' interest.

Therefore, this study can have implications for firms, school academic advisors and professors, management accounting association and chief editors of journals. So, it is suggested that the firms pursue implementing new management accounting techniques and they support students in research in management accounting field. Furthermore, journals should shift their policy from financial accounting and auditing to management accounting papers.

The recommendations based on our findings are for more reinforcement of the management accounting text book specially focusing on requiring syllabus and practical techniques which are more necessary in Iran. In addition, the emphasis of the professional body on developing professional certification and holding some professional workshops and seminars will lead to more interest of students in management accounting and firms' more understanding of new management accounting techniques. Also, educational and research disciplines should increase management accounting courses and support their research. The more interest of accounting students, the more attempts and then, the more qualified experts which results to the well functioning of the industry.

\section{REFERENCES}

[1] Ministry of Economic Affairs and Finance, "The timeline of the legislation and decree of the General Policies Pertaining to Principle 44 of the Constitution and the Laws Based on These Policies," 2008. www.asl44.mefa.gov.ir

[2] B. S. L. Beyk, "Cultural Analyzing of Management Accounting Application," Ninth Congress Accounting in Iran, 2011.

[3] I. Noravesh and B. Mashayekhi, "Management Accounting Education Needs and Priorities: Perception Gap between Academics and Practitioners," Iranian Accounting and Auditing Review, Vol. 12, 2005, pp. 133-161.

[4] J. Z. Szendi and R. C. Elmore, "Management Accounting: Are New Techniques Making In-Roads with Practitioners?" Journal of Accounting Education, Vol. 11, No. 1,
1993, pp. 61-67.

[5] T. Hopper, L. Kirkham, R. Scapens and S. Turley, "Does Financial Accounting Dominate Management Accounting-A Research Note," Management Accounting Research, Vol. 3 No. 4, 1992, pp. 307-311. doi:10.1016/S1044-5005(92)70019-5

[6] C. S. Warrick, B. Daniels and C. Scott, "Accounting Students' Perceptions on Employment Opportunities," Research in Higher Education Journal, Vol. 7, 2010, pp. 110.

[7] P. L. Joshi, W. G. Bremser and J. Al-Ajmi, "Perceptions of Accounting Professionals in the Adoption and Implementation of a Single Set of Global Accounting Standards: Evidence from Bahrain," Advances in Accounting, Incorporating Advances in International Accounting, Vol. 24, No. 1, 2008, pp. 41-48.

[8] I. T. Nelson, V. P. Vendrzyk, J. J. Quirin and R. D. Allen, "No, the Sky Is Not Falling: Evidence of Accounting Student Characteristics at FSA Schools," Issues in Accounting Education, Vol. 17, No. 3, 2002, pp. 269-287.

[9] A. Hoffjan, P. Nevries and R. Stienemann, "Comparative Management Accounting-Literature Review on Similarities and Differences Between Management Accounting in Germanic and Anglophone Countries," 2009. http://www.wiso.unidortmund.de/uc/de/textonly/content/ V4/V44/docs/CMA_UK Germany.pdf

[10] K. Hutaibat, "Interest in the Management Accounting Profession: Accounting Students' Perceptions in Jordanian Universities," Asian Social Science, Vol. 8, No. 3, 2012, pp. 303-316.

[11] C. D. Stolle, "Students' Views of the Public and Industrial Accountant," The Journal of Accountancy, 1976, pp. 106-109.

[12] H. Etemadi, D. Z. Dianati, S. B. Bazaz and R. Parameswaran, "Culture, Management Accounting and Managerial Performance: Focus Iran," Advances in Accounting, incorporating Advances in International Accounting, Vol. 25, No. 2, 2009, pp. 216-225.

[13] C. G. Carpenter and R. H. Strawser, "Job Selection Preferences of Accounting Students," The Journal of Accountancy, 1970.

[14] S. A. Reed and S. H. Kratchman, "A Longitudinal and Cross-sectional Study of Students' Perceptions of the Importance of Job Attributes," Journal of Accounting Education, Vol. 7, No. 2, 1989, pp. 171-193. doi:10.1016/0748-5751(89)90003-1

[15] R. F. Kochanek and C. T. Norgaard, "Student Perceptions of Alternative Accounting Careers," The CPA Journal, Vol. 55, No. 5, 1985, pp. 26-43.

[16] J. Cohen and D. M. Hanno, "An Analysis of Underlying Constructs Affecting the Choice of Accounting as a Major," Issues in Accounting Education, Vol. 8, No. 2, 1993, pp. 219-238. 